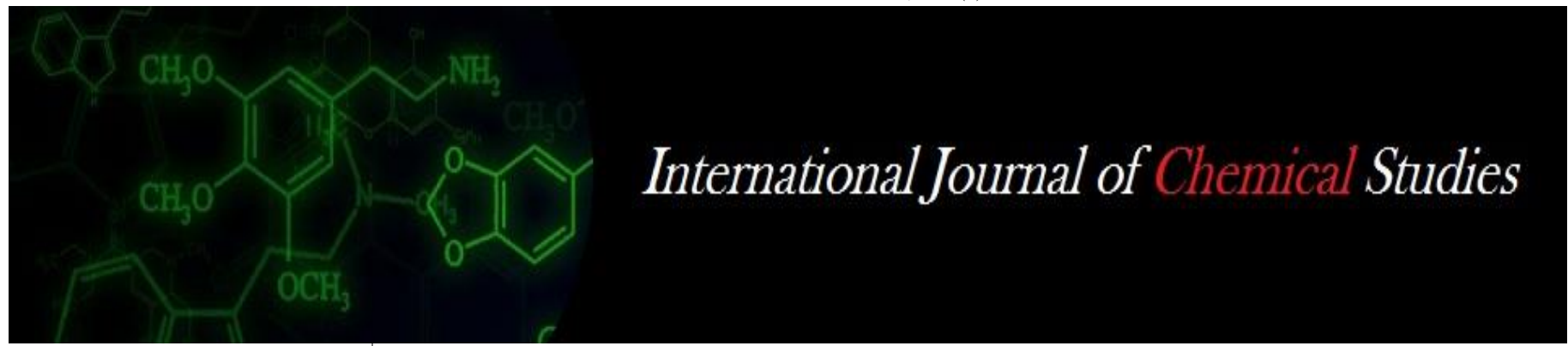

P-ISSN: 2349-8528

E-ISSN: 2321-4902

www.chemijournal.com

IJCS 2020; SP-8(5): 280-286

(C) 2020 IJCS

Received: 25-07-2020

Accepted: 27-08-2020

P Aishwarya

Post Graduate, Department of Agricultural Economics, Tamil Nadu Agricultural University, Agricultural College and Research Institute, Madurai,

Tamil Nadu, India

JS Amarnath

Professor, Department of Agricultural Economics, Tamil Nadu Agricultural University, Agricultural College and Research Institute, Madurai, Tamil Nadu, India

B Sivasankari

Assistant Professor, Department of Agricultural Economics, Tamil

Nadu Agricultural University, Agricultural College and Research Institute, Madurai, Tamil Nadu, India
Corresponding Author: $P$ Aishwarya

Post Graduate, Department of Agricultural Economics, Tamil Nadu Agricultural University, Agricultural College and Research Institute, Madurai, Tamil Nadu, India

\section{An economic evaluation of efficiency and sustainability of Krishnagiri reservoir irrigation project in Krishnagiri district of Tamil Nadu, India}

\section{P Aishwarya, JS Amarnath and B Sivasankari}

DOI: https://doi.org/10.22271/chemi.2020.v8.i5e.10690

\begin{abstract}
About 35 per cent of the India's arable lands are irrigated by irrigation project. Krishnagiri district of Tamil Nadu was purposively selected for the study since the major irrigation in the district is done through Krishnagiri reservoir project having a catchment area of 5428.43 sq.km. It covers a total area of 9012 acres of agricultural land and benefits 26 irrigation tanks on the course of canal. The present study attempts to analyse the economic performance, resource use efficiency of major crops and sustainability of agricultural production for head, middle and tail region. Percentage analysis, Cobb-Douglas production function and sustainability with farm level indicators were the analytical tools used to evaluate the objectives.

The results showed that economic performance for head region was high than middle and tail region in productivity. Water productivity is more efficient for crop consuming less water and higher yield productivity than crop consuming less water and lower yield productivity. The net income was higher for jasmine in middle region than head and tail region by 173.47 per cent and 45.22 per cent. Resource use efficiency result showed that human labour was significant in all the three crops. Seed rate and machine hour was found to be significant in paddy and sugarcane cultivation and plant protection chemical was found to be significant in paddy and jasmine cultivation. Thus the resource use efficiency analyses showed that yield of paddy, jasmine and sugarcane responded to the relevant inputs The sustainability result showed that ecological sustainability favoured head and middle region, economic viability favoured head region and social acceptability favoured middle and head region. Economic productivity and sustainability in middle and tail region has to be improved by reallocating and managing the available water among the users to increase the productivity. Hence proper training should be given to the farmers about proper irrigation scheduling and knowledge of improving the management of existing irrigation facilities by the Department of Agriculture.
\end{abstract}

Keywords: Resource use efficiency, economic efficiency, sustainability, productivity, yield stability, profitability, input self- sufficiency, equity and food security

\section{Introduction}

Irrigation is one among the important factors for assured crop production. About 35 per cent of the India's arable lands are irrigated by irrigation projects which are mostly constructed across the river. The water which is collected in irrigation dams are released to cultivable lands at the right time from sowing to harvesting and also for domestic purpose, water is released from it. Based on the Agricultural census report 2015-16, the total operational holding is about 146 mha, and of which 35 per cent of the land covered under irrigation project schemes. The ultimate sustainable irrigation potential in India has been increased after the construction of many irrigation projects. The present study involves the economic evaluation of Krishnagiri reservoir irrigation project whose performance, productivity, resource use efficiency and sustainability with farm level indicators were analysed at farm level in order to enhance the efficiency of irrigation of farmers in head, middle and tail regions of the project.

\section{Objectives}

1. To study the economic performance in head, middle and tail regions of Krishnagiri reservoir irrigation project 
2. To study the resource use efficiency and economic efficiency of major crops in head, middle and tail regions of Krishnagiri reservoir irrigation project

3. To study the Indicators of sustainability with farm level indicators in head, middle and tail regions of Krishnagiri reservoir irrigation project

\section{Methodology}

The sample selected for the study area comes under two blocks namely Krishnagiri and Kaveripattinam and the area was differentiated into three regions as head, middle and tail regions based on the reach (distance) of the water discharge data provided by Public Works Department and based on cropping pattern. From the study area, 40 respondents were selected at random from each of the three different regions of Cultivable Command Area of the irrigation project. Totally 120 respondents were selected from the study area. Thus multi stage random sampling was adopted for the study.

\subsection{Functional analysis}

Production function analysis was employed to evaluate the resource use efficiency of Paddy in head region, Jasmine in middle region and Sugarcane in tail region of the command area respectively. Per hectare Cobb- Douglas production function was employed for the study.

The form of regression model used was

$\mathrm{Y}=\mathrm{a} \mathrm{X}_{1}{ }^{\mathrm{b} 1} \mathrm{X}_{2}{ }^{\mathrm{b} 2} \mathrm{X}_{3}{ }^{\mathrm{b} 3} \mathrm{X}_{4}{ }^{\mathrm{b} 4} \mathrm{X}_{5}{ }^{\mathrm{b} 5} \mathrm{X}_{6}{ }^{\mathrm{b} 6} \mathrm{X}_{7}{ }^{\mathrm{b} 7} \mathrm{U}_{\mathrm{t}}$

Where,

$\mathrm{Y}=$ Yield (kgs /tonnes/ha)

$\mathrm{X}_{1}=$ Quantity of seed material (kgs/bundles/no./ha)

$\mathrm{X}_{2}=$ Quantity of nitrogen $(\mathrm{kgs} / \mathrm{ha})$

$\mathrm{X}_{3}=$ Quantity of phosphorus (kgs /ha)

$\mathrm{X}_{4}=$ Quantity of potassium (kgs /ha)

$\mathrm{X}_{5}=$ Human labour (man days/ha)

$\mathrm{X}_{6}=$ Machine hours (hrs/ha)

$\mathrm{X}_{7}=$ Plant Protection chemicals (lit / ha)

$\mathrm{U}_{\mathrm{t}}=$ Error term

$a, b_{1}, b_{2}, \ldots \ldots . b_{7}=$ Parameters to be estimated

\subsection{Economic efficiency}

The economic efficiency of resource use and the Marginal Value Products of each input were compared with its MIC in order to estimate the efficiency. Equality of $\mathrm{MVP}_{\mathrm{j}}$ to the MIC of input ' $\mathrm{j}$ ' indicates the optimum resource use of a particular input. Ratio of $\mathrm{MVP}_{\mathrm{j}}$ to the MIC of input ' $\mathrm{j}$ ' indicated the degree of resource use efficiency.

\subsection{Indicators of sustainability}

The three basic features of sustainable agriculture are: (i) maintenance of environmental quality, (ii) stable crop productivity, and (iii) social acceptability. Consistent with this, agricultural sustainability was assessed from the perspectives of ecological soundness, social acceptability and economic viability. Hatai LD and Sen C (2008) [2] study analyzed the agricultural sustainability in Orissa by using these concepts. It was assessed based on four indicators of land use pattern, cropping pattern, soil fertility status and pest and disease management. Economic viability refers to the maintenance of yields and productivity of crops and livestock. It was assessed based on three indicators; land productivity, yield stability and profitability from stable crops. Social acceptability refers to self- reliance, equality and improved quality of life. It was assessed in terms of input selfsufficiency, equity and food security.

\section{Results and Discussion}

4.1 Economic performance of head, middle and tail regions of Krishnagiri reservoir irrigation project 4.1.1 Average Productivity of major crops

Productivity of major crops for the head, middle and tail region of Krishnagiri reservoir irrigation project is furnished in Table 1.

Table 1: Productivity of major crops in head, middle and tail region of Krishnagiri reservoir irrigation project

\begin{tabular}{|c|c|c|c|}
\hline Region & Major crops & Yield $\left(\mathrm{t} \mathrm{ha}^{-1}\right)$ & Water Productivity $\left(\mathrm{kg} \mathrm{m}^{-3}\right)$ \\
\hline \multirow{2}{*}{ Head } & Paddy & 7.53 & 6.28 \\
\hline & Tomato & 31.51 & 42.01 \\
\hline \multirow{4}{*}{ Middle } & Paddy & 6.98 & 5.97 \\
\hline & Jasmine & 3.75 & 2.83 \\
\hline & Tomato & 30.20 & 41.09 \\
\hline & Ragi & 3.14 & 4.83 \\
\hline \multirow{5}{*}{ Tail } & Sugarcane & 98.54 & 8.76 \\
\hline & Paddy & 5.70 & 5.85 \\
\hline & Tomato & 29.23 & 40.60 \\
\hline & Jasmine & 2.98 & 2.34 \\
\hline & Ragi & 2.89 & 3.68 \\
\hline
\end{tabular}

It could be seen from the table 1, that productivity of paddy in head region of irrigation project was highest with $7.53 \mathrm{t} / \mathrm{ha}$ as compared to middle and tail region which are observed with $6.98 \mathrm{t} / \mathrm{ha}$ and $5.70 \mathrm{t} / \mathrm{ha}$ respectively and the increase of crop productivity in head region was 15.85 per cent and 32.12 per cent over middle region and tail region respectively. In jasmine, middle region was registered highest with $3.75 \mathrm{t} / \mathrm{ha}$ and tail region productivity was $2.98 \mathrm{t} / \mathrm{ha}$ and the increase of productivity in middle region was 25.84 per cent over tail region productivity. Tomato productivity was highest in head region with $31.51 \mathrm{t} / \mathrm{ha}$ and increase of productivity by 4.34 per cent and 7.80 per cent as compared to middle and tail region respectively. Ragi was cultivated only in middle and tail region with highest productivity of $3.14 \mathrm{t} / \mathrm{ha}$ in middle region and the increased productivity over tail region was by 8.65 per cent. Sugarcane, Banana and Mango crops were cultivated only in tail region. Thus it could be seen from the table that the productivity of crops under head region was higher than the middle and tail region of the irrigation project. Water productivity is estimated to measure the relationship between crop yield and the amount of water involved in production of crop. It is a robust measure of the ability of agricultural systems to convert water into food based on the works of Sharma et al, (2015) ${ }^{[6]}$. The estimated value of water productivity for major crops in head, middle and tail region of Krishnagiri reservoir irrigation project is furnished in table 1. It could be seen from the table 1 , that water productivity of paddy in head, middle and tail region are 6.28 $\mathrm{kg} \mathrm{m} \mathrm{m}^{-3}, 5.97 \mathrm{~kg} \mathrm{~m}^{-3}$ and $5.85 \mathrm{~kg} \mathrm{~m}^{-3}$ respectively. Water productivity of tomato in head, middle and tail regions are $42.01 \mathrm{~kg} \mathrm{~m}^{-3}, 41.09 \mathrm{~kg} \mathrm{~m}^{-3}$ and $40.60 \mathrm{~kg} \mathrm{~m}^{-3}$ respectively. Water productivity in head region was high for paddy and tomato. Jasmine water productivity was highest in middle region with $2.83 \mathrm{~kg} \mathrm{~m}^{-3}$ followed by tail region with $2.34 \mathrm{~kg}$ $\mathrm{m}^{-3}$. Sugarcane water productivity in tail region was $8.76 \mathrm{~kg}$ $\mathrm{m}^{-3}$. Sharma et.al, (2015) ${ }^{[6]}$ study plotted the variation of paddy water productivity among Indo-Gangetic basin with the range of $0.08-9.68 \mathrm{kgm}^{-3}$. This study also showed the water productivity of sugarcane and millet in Mekong and Volta 
basin with $9.81 \mathrm{kgm}^{-3}$ and $0.10 \mathrm{kgm}^{-3}$ respectively. Parameshwarareddy et al, (2018) ${ }^{[3]}$ study showed the highest water productivity of tomato under drip irrigation $74.56 \mathrm{~kg} \mathrm{~m}^{-}$ 3. Playan E and Mateos L (2006) ${ }^{[4]}$ study explained various techniques of irrigation systems to increase water productivity. It could be concluded from the result that water productivity is more efficient for crop consuming less water and higher yield productivity than crop consuming less water and lower yield productivity.

\subsubsection{Cost and returns in Paddy, jasmine and sugarcane cultivation}

The costs and returns for the sample farms in paddy, jasmine and sugarcane cultivation was worked out and the results are given in Table 2.

Table 2: Costs and returns in paddy, jasmine and sugarcane cultivation (in Rs/ha)

\begin{tabular}{|c|c|c|c|c|}
\hline S. No. & Particulars & Paddy & Jasmine & Sugarcane \\
\hline \multirow{2}{*}{1} & Fixed cost & $\begin{array}{c}49428 \\
(37.83)\end{array}$ & $\begin{array}{c}42585 \\
(19.00)\end{array}$ & $\begin{array}{c}47408 \\
(27.43)\end{array}$ \\
\hline \multirow{2}{*}{2} & \multirow{2}{*}{ Variable cost } & $\begin{array}{c}81245 \\
(62.17)\end{array}$ & $\begin{array}{c}181498 \\
(81.00)\end{array}$ & $\begin{array}{c}125449 \\
(72.57)\end{array}$ \\
\hline \multirow{2}{*}{3} & \multirow{2}{*}{ Total cost of cultivation } & $\begin{array}{c}130673 \\
(100.00)\end{array}$ & $\begin{array}{c}224083 \\
(100.00)\end{array}$ & $\begin{array}{c}172857 \\
(100.00)\end{array}$ \\
\hline 4 & Gross income & 195000 & 400000 & 294000 \\
\hline & Net income & 64327 & 175917 & 121143 \\
\hline
\end{tabular}

Figures in parentheses indicate percentage to total

It could be observed from the table 2 that fixed cost occupied lower proportion of 37.83 per cent, 19.00 per cent, and 27.43 per cent in paddy, jasmine and sugarcane cultivation respectively. The share of total variable cost to the total cost of cultivation was high with 62.17 per cent, 81.00 per cent and 72.57 per cent in paddy, jasmine and sugarcane cultivation respectively. The gross income was high in jasmine with Rs.4.00 lakhs and it was higher over paddy and sugarcane cultivation by 105.13 per cent and 36.05 per cent respectively. The net income in jasmine cultivation was high with Rs.1.76 lakhs and it was high over paddy and sugarcane cultivation by 173.47 per cent and 45.22 per cent respectively. The total cost of cultivation was high for jasmine with Rs.2.24 lakhs per hectare and it was high over paddy and sugarcane by 71.48 per cent and 29.64 per cent respectively. Thus it could be concluded from the table that jasmine cultivation in middle region had high net returns over sugarcane and paddy cultivation in tail and head region respectively and it showed that jasmine is more profitable than paddy and sugarcane cultivation.

\subsection{Resource use efficiency of major crops in head, middle} and tail region of Krishnagiri reservoir irrigation project

The estimated Cobb-Douglas production function for paddy, jasmine and sugarcane in head, middle and tail region of the irrigation project is furnished in Table 3 .

\subsubsection{Resource use efficiency of paddy production in head region}

It could be seen from the Table 3 that the yield responded significantly to the inputs of seed rate, potassium, human labour, machine hours and plant protection chemicals. The coefficient of human labour, machine hours and plant protection chemicals were positive and significant at one per cent level with the coefficient values of $0.18,0.25$ and 0.34 respectively. These positive coefficient values indicated that an increase in the usage of human labour, machine hours and plant protection chemicals by one per cent from the existing mean level, ceteris paribus, would increase the yield of paddy by $0.18,0.25$ and 0.34 per cent respectively. The coefficient of seed rate and potassium variables were negative with the values of- 0.34 and -0.06 indicating that one per cent increase in seed rate and potassium usage from the existing mean level, ceteris paribus would decrease the yield of paddy by 0.34 and 0.06 per cent respectively. The variable seed rate was significant at five per cent level and potassium was significant at one per cent level.

Table 3: Resource use Efficiency of Paddy (Head), Jasmine (Middle) and Sugarcane (Tail) Production

\begin{tabular}{|c|c|c|c|c|}
\hline $\begin{array}{c}\text { S. } \\
\text { No. }\end{array}$ & Variables & $\begin{array}{c}\text { Head } \\
\text { region }\end{array}$ & $\begin{array}{c}\text { Middle } \\
\text { region }\end{array}$ & $\begin{array}{c}\text { Tail } \\
\text { region }\end{array}$ \\
\hline 1 & Regression Constant & $2.21^{* *}$ & $-1.28^{\mathrm{NS}}$ & $6.30^{\mathrm{NS}}$ \\
\hline 2 & Seed rate (kg/ha) & $-0.34^{*}$ & $0.13^{\mathrm{NS}}$ & $-0.05^{* *}$ \\
\hline 3 & Nitrogen (kg/ha) & $0.05^{\mathrm{NS}}$ & $0.08^{*}$ & $0.02^{*}$ \\
\hline 4 & Phosphorus (Kg/ha) & $0.06^{\mathrm{NS}}$ & $0.14^{* *}$ & $0.07^{\mathrm{NS}}$ \\
\hline 5 & Potassium (kg/ha) & $-0.06^{* *}$ & $0.01^{\mathrm{NS}}$ & $0.11^{\mathrm{NS}}$ \\
\hline 6 & Human labour(man days/ha) & $0.18^{* *}$ & $0.04^{* *}$ & $0.13^{* *}$ \\
\hline 7 & Machine hours (hrs/ha) & $0.25^{* *}$ & $0.08^{\mathrm{NS}}$ & $0.04^{*}$ \\
\hline 8 & $\begin{array}{c}\text { Plant protection chemicals } \\
\text { (lit/ha) }\end{array}$ & $0.34^{* *}$ & $-0.07^{* *}$ & $0.01^{\mathrm{NS}}$ \\
\hline 9 & ${\text { Adjusted } \mathrm{R}^{2}}^{2}$ & 0.77 & 0.71 & 0.79 \\
\hline
\end{tabular}

**Significant at 1 percent level; $*$ Significant at 5 percent level and NS-Non-significant

\subsubsection{Resource use efficiency of jasmine production in middle region}

The estimated Cobb-Douglas production function of jasmine in middle region is mentioned in table 3 . It could be observed that the yield responded significantly to the inputs such as nitrogen, phosphorus, human labour, and plant protection chemicals. The coefficient of nitrogen, phosphorus and human labour were positive with the coefficient values of $0.08,0.14$ and 0.04 respectively which indicated that an increase in the usage of nitrogen, phosphorus and human labour by one per cent from the existing mean level, ceteris paribus, would increase the yield of jasmine by $0.08,0.14$ and 0.04 per cent respectively. The variable plant protection chemical was negative and indicating that one per cent change inplant protection chemical from the existing mean level, ceteris paribus would decrease the yield of jasmine by 0.07 per cent. The variables phosphorus, human labour, and plant protection chemicalswere significant at one percent level and the variable nitrogen was significant at five per cent.

\subsubsection{Resource use efficiency of sugarcane production in tail region}

The estimated Cobb-Douglas production function for sugarcane in tail region of the irrigation project is furnished in Table 3. It could be seen from the table that yield responded significantly to the inputs of seed rate, nitrogen, human labour and machine hours. The coefficient of nitrogen, human labour and machine hours were positive with the coefficient values of $0.02,0.13$ and 0.04 respectively, which indicated that an increase in the usage of nitrogen, human labour and machine hours by one per cent from the existing mean level, ceteris paribus would increase the yield of sugarcane by $0.02,0.13$ and 0.04 per cent respectively. The variable human labour was significant at one percent level and the variables nitrogen and machine hours were significant at five per cent level. The coefficient of seed rate variable was found to be negative and significant at one per cent level indicating that one per cent 
change in seed rate from the existing mean level, ceteris paribus would decrease the yield of sugarcane by 0.05 per cent.

\subsection{Economic efficiency of major crops in head, middle and tail region of Krishnagiri reservoir irrigation project} The ratio between Marginal Value of Product (MVP) and Marginal Input Cost (MIC) was worked out for each input to understand the efficiency of input use. Economic Efficiency of Resource use paddy, jasmine and sugarcane production in head, middle and tail regionof irrigation project is presented in the table 4.

Table 4: Economic Efficiency of Resource use Paddy (Head), Jasmine (Middle) and Sugarcane (Tail) Production

\begin{tabular}{|c|c|c|c|c|}
\hline $\begin{array}{c}\text { S. } \\
\text { No. }\end{array}$ & Variables & $\begin{array}{c}\text { Head } \\
\text { region }\end{array}$ & $\begin{array}{c}\text { Middle } \\
\text { region }\end{array}$ & $\begin{array}{c}\text { Tail } \\
\text { region }\end{array}$ \\
\hline 1 & Seed rate $(\mathrm{kg} / \mathrm{ha})$ & -14.06 & - & -0.03 \\
\hline 2 & Nitrogen $(\mathrm{kg} / \mathrm{ha})$ & - & 6.38 & 2.56 \\
\hline 3 & Phosphorus $(\mathrm{kg} / \mathrm{ha})$ & - & 3.23 & - \\
\hline 4 & Potassium $(\mathrm{kg} / \mathrm{ha})$ & -1.66 & - & - \\
\hline 5 & Human labour (man days/ha) & 1.12 & 0.49 & 0.29 \\
\hline 6 & Machine hours (hrs/ha) & 0.94 & - & 1.27 \\
\hline 7 & Plant protection chemicals (lit/ha) & 5.18 & -31.71 & - \\
\hline
\end{tabular}

It could be seen from the Table 4 that in head region the ratio between MVP and MIC of human labour and plant protection chemicals was found to be greater than one. It indicated that the above resources are at sub optimum level and there exists a possibility for enhancing the yield of paddy by increasing the respective inputs from the existing level. The reduction in seed rate, potassium and machine hours from the existing mean level was required since MVP is less than MIC. This shows the over utilization level of seed rate, potassium and machine hours in paddy cultivation of head region.

In middle region, that the ratio between MVP and MIC of nitrogen and phosphorus was found to be greater than one and indicating the sub-optimal utilization of the resources and there exists a possibility for enhancing the yield of jasmine by increasing the respective input from the existing level. The reduction in human labour and plant protection chemicals from the existing mean level was required since MVP is less than MIC indicating the over- utilization level of these particular inputs.

It could be seen from the Table 4 that, in tail region the ratio between MVP and MIC of nitrogen and machine hours was found to be greater than one and indicating the sub-optimal utilization of the resources and there exists a possibility for enhancing the yield of sugarcane by increasing the respective input from the existing level. The reduction in seed rate and human labour from the existing mean level was required, since the ratio between MVP and MIC was lesser than one indicating the over- utilization level of these particular inputs. Thus the resource use efficiency analyses showed that yield of paddy, jasmine and sugarcane responded to the relevant inputs.

\subsection{Indicators of sustainability with farm level indicators} Agricultural sustainability was assessed by combining the three sustainability criteria of ecological soundness, economic viability and social acceptability. Amarnath JS and Saranya S (2014) ${ }^{[1]}$ studied the sustainability of irrigated and rainfed agro ecological system by using these indicators.

\subsubsection{Ecological Sustainability}

Ecological Sustainability was assessed based on land use pattern, cropping pattern, soil fertility management, use of chemical fertilizer and management of pests and diseases. These were analysed for all three regions of irrigation project and are discussed below.

\subsubsection{Land use pattern}

It could be seen from the table 5 that net area sown was highest with 63.84 per cent, 58.82 per cent and 33.95 per cent in head, middle and tail region of the irrigation project respectively. The percentage of land put to non-agricultural uses was next highest with 13.10 per cent of total geographical area in head region of the irrigation project indicating that the agricultural land had been diverted to nonagricultural purpose which indicated the land utilization for industrial activities. In middle region, the percentage of area under current fallow was second highest with 12.28 per cent of total geographical area.In tail region of the irrigation project forest occupied the second highest proportion with 22.75 per cent to the total geographical area. Thus it could be concluded from Table 5 that net area sown was high in head and middle region over tail region of the irrigation project. Further, the tail region of irrigated project required the situation of arresting the conversion of land for nonagricultural uses. The middle and head region of the irrigation project presented the scope for increasing the net area sown by converting current fallow lands into agricultural lands with suitable technological interventions.

Table 5: Land use pattern of sample villages (in ha.)

\begin{tabular}{|c|c|c|c|c|}
\hline S. No & Particulars & Head regio & iddle regi & ail region \\
\hline 1 & Forest & - & - & $\begin{array}{l}848.10 \\
(22.75)\end{array}$ \\
\hline 2 & Barren and Uncultivable land & $\begin{array}{l}33.90 \\
(1.69)\end{array}$ & $\begin{array}{l}35.80 \\
(1.34)\end{array}$ & $\begin{array}{l}148.90 \\
(3.99)\end{array}$ \\
\hline 3 & Land put to Non Agricultural uses & $\begin{array}{l}263.40 \\
(13.10)\end{array}$ & $\begin{array}{c}191.70 \\
(7.17)\end{array}$ & $\begin{array}{l}689.50 \\
(18.49)\end{array}$ \\
\hline 4 & Cultivable Waste & $\begin{array}{l}54.80 \\
(2.73)\end{array}$ & $\begin{array}{c}241.00 \\
(9.02)\end{array}$ & $\begin{array}{l}127.40 \\
(3.42)\end{array}$ \\
\hline 5 & Permanent Pastures and other grazing lands & $\begin{array}{l}22.50 \\
(1.12) \\
\end{array}$ & $\begin{array}{r}12.80 \\
(0.48) \\
\end{array}$ & $\begin{array}{l}24.60 \\
(0.66) \\
\end{array}$ \\
\hline 6 & Land under miscellaneous tree crops and groves not included in net area Sown & $\begin{array}{l}143.10 \\
(7.12)\end{array}$ & $\begin{array}{c}203.40 \\
(7.61)\end{array}$ & $\begin{array}{c}346.30 \\
(9.29)\end{array}$ \\
\hline 7 & Current Fallow & $\begin{array}{l}135.10 \\
(6.72)\end{array}$ & $\begin{array}{l}328.20 \\
(12.28)\end{array}$ & $\begin{array}{l}175.20 \\
(4.70)\end{array}$ \\
\hline 8 & Other fallow lands & $\begin{array}{l}74.40 \\
(3.70)\end{array}$ & $\begin{array}{l}87.40 \\
(3.27)\end{array}$ & $\begin{array}{c}102.40 \\
(2.75)\end{array}$ \\
\hline
\end{tabular}




\begin{tabular}{|c|c|c|c|c|}
\hline 9 & Net area sown & 1283.80 & 1571.80 & 1265.90 \\
$(63.84)$ & $(58.82)$ & $(33.95)$ \\
\hline \multirow{2}{*}{$\mathrm{I}$} & \multirow{2}{*}{ Total geographical area } & 2011.00 & 2672.10 & 3728.30 \\
& & $(100.00)$ & $(100.00)$ & $(100.00)$ \\
\hline
\end{tabular}

Figures in parentheses indicate percentage to total

Source: Village - G return, Department of Economics and Statistics

\subsubsection{Cropping pattern}

The cropping intensity was higher in head region with 172.68 , followed by middle and tail region of the irrigation project with 148.02 and 131.71 respectively. This may be attributed to the practice of jasmine and sugarcane in the middle and tail regions of the irrigation project.Crop diversification index for the head, middle and tail region of the irrigation project was $0.62,0.85$ and 0.84 respectively. Thus the indices of cropping intensity and crop diversification revealed that there was no significant variation in middle and tail region of the irrigation project. The crop diversification is significant in enhancing the agricultural output. Crop diversification index was higher in middle and tail regions of irrigation project showing higher diversification. Further, crop diversification index in middle and tail region was closer to one which shows the sustainability of these regions.

\subsubsection{Soil fertility status}

Soil fertility status is presented in Table 6 . It could be seen from the table that nitrogen content was low in all three regions of irrigation project. Phosphorous content was high in head and middle region of the irrigation project and it wasmedium in tail region of the irrigation project. Potassium content was high in head and tail region of the irrigation project and medium in middle region of the irrigation project. The organic content was medium in middle region of the irrigation project and low in head and tail region of the irrigation project respectively.

Table 6: Average input use in the sample farms

\begin{tabular}{|c|c|c|c|c|}
\hline $\begin{array}{c}\text { S. } \\
\text { No }\end{array}$ & Input & $\begin{array}{c}\text { Head } \\
\text { region }\end{array}$ & $\begin{array}{c}\text { Middle } \\
\text { region }\end{array}$ & $\begin{array}{c}\text { Tail } \\
\text { region }\end{array}$ \\
\hline 1. & FYM (t/ha) & 9.15 & 10.26 & 5.45 \\
\hline 2. & Fertilizer (Kg/ha) & 345.18 & 410.25 & 495.86 \\
\hline 3. & $\begin{array}{c}\text { Plant protection } \\
\text { chemical (lit/ha) }\end{array}$ & 4.17 & 5.26 & 4.15 \\
\hline 4. & Labour (in man days) & 139.93 & 217.08 & 150.82 \\
\hline
\end{tabular}

It could be observed from the table 6 that farmers applied about $10.26 \mathrm{t} / \mathrm{ha}$ and $9.15 \mathrm{t} / \mathrm{ha}$ of FYM in middle and head region of the irrigation project while in tail region, it was only $5.45 \mathrm{t} / \mathrm{ha}$. Use of chemical fertilizer was also more in tail region of the irrigation project with $495.86 \mathrm{~kg} / \mathrm{ha}$ than the middle and head region with 410.25 and 345.18 respectively. The usage of PPC was higher in middle region with 6.15 lit/ha and in head and tail region was 4.17 lit/ha and 4.15 lit/ha respectively. Labour employment was also higher in middle region of the irrigation project than head and tail region as already discussed (vide Table 3)

\subsubsection{Pest and disease management}

The pest and disease management in head, middle and tail region of the irrigation project was presented in Table 7 . It could be observed from the table 7 that there was slight variation between head and middle regions of the irrigation project in the management of pest and disease. In middle region of the irrigation project, higher proportion of the farmers with 62.50 per cent followed both chemical and biological control methods for controlling pest and diseases and 35.00 per cent of farmers applied pesticide alone and only 2.50 percent used biological control alone. Head region also had higher proportion of farmers with 60.00 per cent using both chemical and biological control methods and 40.00 per cent of farmers applied pesticide alone for controlling pests and disease. In tail region most of the farmer followed chemicals alone with a proportion of 57.50 per cent and 42.50 per cent of farmers are using chemical and biological control methods for managing pest and diseases. It could be concluded that the farmers using both chemical and biological management were high in middle and head regionwith 62.50 per cent and 60.00 per cent respectively.

Table 7: Pest and Disease Management in the sample farms (in nos.)

\begin{tabular}{|c|c|c|c|c|}
\hline $\begin{array}{c}\text { S. } \\
\text { No. }\end{array}$ & Particulars & $\begin{array}{c}\text { Head } \\
\text { region }\end{array}$ & $\begin{array}{c}\text { Middle } \\
\text { region }\end{array}$ & $\begin{array}{c}\text { Tail } \\
\text { region }\end{array}$ \\
\hline 1. & Chemical alone & $18(40.00)$ & $14(35.00)$ & $33(57.50)$ \\
\hline 2. & Biological Control alone & - & $1(2.50)$ & - \\
\hline 3. & $\begin{array}{c}\text { Both chemical and } \\
\text { biological }\end{array}$ & $22(60.00)$ & $25(62.50)$ & $7(42.50)$ \\
\hline 4. & Total & $40(100.00)$ & $40(100.00)$ & $40(100.00)$ \\
\hline
\end{tabular}

Figures in parentheses indicate percentage to total

Thus the ecological sustainability analyses showed that both head and middle region of the irrigation project favoured well from the point of view of soil fertility status by low fertilizer consumption, higher organic manure application, soil test value and also by following integrated pest management. Preetha GS and Amarnath JS (2019) ${ }^{[5]}$ study analysed the sustainability in different irrigation regimes of Coimbatore district.

\subsubsection{Economic viability}

It was assessed based on three indicators of land productivity, yield stability and profitability of crops.

\subsubsection{Productivity}

The productivity analyses (vide Table No 1) revealed that the productivity of farms under head region of the irrigation project was higher than the farms under middle and tail region.

\subsubsection{Stability of yield}

The stability of crop yield was examined by constructing an index based on farmer's subjective response to a question related to yield trend. In head region of the irrigation project, the index of yield stability was 0.83 followed by middle region with the yield stability of 0.68 and tail region with yield stability of 0.49 which indicated the order of stability.

\subsubsection{Profitability}

The profitability of cropping system was analyzed based on financial and economic returns and value-addition per unit of land to understand the performance of an agricultural system. The results have been presented in Table 8 . 
Table 8: Profitability of Major principle crop in the sample farms (inRs/ha)

\begin{tabular}{|c|c|c|c|c|}
\hline $\begin{array}{c}\text { S. } \\
\text { No. }\end{array}$ & Particulars & $\begin{array}{c}\text { Head } \\
\text { region }\end{array}$ & $\begin{array}{c}\text { Middle } \\
\text { region }\end{array}$ & $\begin{array}{c}\text { Tail } \\
\text { region }\end{array}$ \\
\hline i. & $\begin{array}{c}\text { Output-input } \\
\text { ratio }\end{array}$ & 2.40 & 2.20 & 2.34 \\
\hline ii. & Net return & 64327 & 175917 & 121143 \\
\hline iii. & $\begin{array}{c}\text { Value- } \\
\text { addition* }\end{array}$ & 171055 & 360662 & 251389 \\
\hline
\end{tabular}

*Value-addition $=$ Gross return-Cost of intermediate goods

It has been found that performance of head region of the irrigation project was slightlybetter than middle and tail region as the output-input ratio was 2.40 in head region followed by tail region with the output-input ratio of 2.34 . Net return was higher in middle region with Rs.1.76 lakhs followed by tail region with Rs.1.21 lakhs. The value addition was found to be higher in middle region with Rs.3.61 lakhs followed by tail region with Rs.2.51 lakhs and head region with Rs.1.71 lakhs. Head region of the irrigation project was lowest with net return and value addition cost because the major principle crop was paddy of shorter duration and the profitability was calculated for one season.

Thus the economic viability analyses showed that head region was more sustainable by having higher productivity, higher stability and higher output-input ratio followed by middle region with highest net return and value addition and second highest position in higher productivity and higher yield stability as compared to tail region of the irrigation project.

\subsubsection{Social acceptability}

It was assessed in terms of input self-sufficiency, equity, and food security.

\subsubsection{Input self-sufficiency}

Input self-sufficiency in the study area was analyzed and presented in Table 9. It could be seen from the table that in middle region, the dependency on local inputs was high with high input self-sufficiency ratio of 0.78 followed by head region with 0.71 of input self-sufficiency ratio and tail region with input self-sufficiency ratioof 0.66 respectively. It clearly showed that middle region was relatively more sustainable in terms of local input dependency than head and tail region.

Table 9: Input self sufficiency (in Rs/ha)

\begin{tabular}{|c|c|c|c|c|}
\hline $\begin{array}{c}\text { S. } \\
\text { No. }\end{array}$ & Particulars & $\begin{array}{c}\text { Head } \\
\text { region }\end{array}$ & $\begin{array}{c}\text { Middle } \\
\text { region }\end{array}$ & $\begin{array}{c}\text { Tail } \\
\text { region }\end{array}$ \\
\hline 1. & $\begin{array}{c}\text { Cost of all } \\
\text { variable inputs }\end{array}$ & $\begin{array}{c}81245 \\
(100.00)\end{array}$ & $\begin{array}{c}181498 \\
(100.00)\end{array}$ & $\begin{array}{c}125449 \\
(100.00)\end{array}$ \\
\hline 2. & $\begin{array}{c}\text { Cost of local } \\
\text { inputs }\end{array}$ & $\begin{array}{c}33250 \\
(70.53)\end{array}$ & $\begin{array}{c}40621 \\
(78.33)\end{array}$ & $\begin{array}{c}16554 \\
(66.03)\end{array}$ \\
\hline 3. & $\begin{array}{c}\text { Cost of external } \\
\text { inputs }\end{array}$ & $\begin{array}{c}23945 \\
(29.47)\end{array}$ & $\begin{array}{c}39338 \\
(21.67)\end{array}$ & $\begin{array}{c}42611 \\
(33.97)\end{array}$ \\
\hline 4. & $\begin{array}{c}\text { Input self- } \\
\text { sufficiency ratio* }\end{array}$ & 0.71 & 0.78 & 0.66 \\
\hline
\end{tabular}

* Input self-sufficiency ratio $=$ Cost of local inputs / Cost of all variable inputs

\subsubsection{Equity}

The details of equity and food security are given in Table 10 . It could be observed from the table that labour requirement to produce one $\mathrm{kg}$ of paddy was 1.23 man days in head region and to produce one $\mathrm{kg}$ of jasmine was 2.78 man days in middle region. Similarly the labour requirement to produce one $\mathrm{kg}$ of sugarcane was 1.69 man days in tail region. The same was reflected in the labour cost per unit of output.
Thereby middle region of the irrigation project was more sustainable from the equity point of view as compared to other regions.

Table 10: Equity and Food security

\begin{tabular}{|c|c|c|c|c|}
\hline $\begin{array}{c}\text { S. } \\
\text { No. }\end{array}$ & Particulars & $\begin{array}{c}\text { Head } \\
\text { region }\end{array}$ & $\begin{array}{c}\text { Middle } \\
\text { region }\end{array}$ & $\begin{array}{c}\text { Tail } \\
\text { region }\end{array}$ \\
\hline 1. & \multicolumn{4}{|c|}{ Equity } \\
\hline i. & $\begin{array}{c}\text { Labour requirement } \\
\text { to produce one unit } \\
\text { of output }\end{array}$ & 1.23 & 2.78 & 1.69 \\
\hline ii. & $\begin{array}{c}\text { Labour cost per unit } \\
\text { of output (₹) }\end{array}$ & 450.25 & 550.50 & 500.25 \\
\hline 2. & \multicolumn{3}{|c|}{ Food security } \\
\hline i. & $\begin{array}{c}\text { Expenditure on food } \\
\text { items }\end{array}$ & 81650.87 & 73589.42 & 70938.69 \\
\hline
\end{tabular}

\subsubsection{Food security}

Food security was measured in terms of household's food expenditure on food items. The expenditure on food items was Rs.81650.87, Rs. 73589.42 and Rs.70938.69 in head, middle and tail region respectively. (Table 10). Food expenditure in head region was higher when compared to middle and tail region and it is more food secure. Thus with regard to social acceptability middle region was more sustainable by high input self-sufficiency ratio and higher equity as compared to other regions. Thus the sustainability analyses showed that head and middle regions were more sustainable than tail region

\section{Conclusions and Policy implications}

Economic performance with respect to productivity of paddy and tomato and sustainability ascertained through farm level indicators was higher in head region over middle and tail region. This has to be improved in middle and tail region by reallocating and managing the available water among the users. Hence proper training should be given to the farmers about proper irrigation scheduling and knowledge of improving the management of existing irrigation facilities by the Department of Agriculture. Tail region has to restore the soil fertility of land by applying the fertilizers at required level. Awareness about soil health card status has to be developed among the farmers by agricultural extension department.

The results of economic efficiency of paddy in head region showed that human labour and plant protection chemicals was at sub optimum level and over utilization level of seed rate, potassium and machine hours. In middle region, nitrogen and phosphorus was at sub-optimal level and human labour and plant protection chemicals indicated over- utilization. In tail region, nitrogen and machine hour indicated the sub-optimal utilization and over utilization of seed rate and human labour was found.Hence extension infrastructure of Agricultural Department should conduct training programme on effective usage of inputs and machineries for crop production. Government has to ensure the availability of fertilizers at nominal price to the farmers in time.

\section{References}

1. Amarnath JS, Saranya S. An economic analysis of sustainability in Namakkal district of Tamil Nadu. Wyno Academic Journal of Agricultural Sciences 2014;2(1):118. 
2. Hatai LD, Sen C. An economic analysis of agricultural sustainability in Orissa. Agricultural Economics Research Review 2008; 21:273-282.

3. Parameshwarareddy R, Angadi SS, Biradar MS, Patil RH. Water productivity of tomato as influenced by drip irrigation levels and substrates. Journal of Pharmacognosy and Phytochemistry 2018;7(2):13431346.

4. Playán E, Mateos L. Modernization and optimization of irrigation systems to increase water productivity. Agricultural water management 2006;80(1-3):100-16.

5. Preetha GS, Amarnath JS. An economic analysis of sustainability in different irrigation regimes of Coimbatore district. International Journal of Agricultural Science and Research 2019;9(4):91-100.

6. Sharma B, Molden D, Cook S. Water use efficiency in agriculture: measurement, current situation and trends managing water and fertilizer for sustainable agricultural intensification. Paris 2015, 39-64. 